\title{
Dávid Gyula
}

\section{Kossuth és Petőfi}

Két fogalommá lett név, amelyeknek viselöi az utódok tudatában együtt és különkülön is ugyanazt az eszmét fejezik ki: a szabadságvágyat és a szabadság ügyéért hozott legnagyobb áldozatot. Petőfi az életét adta érte a fehéregyházi csatában, Kossuth a szabadságharc véres letörése után a számüzetést választva volt közel egy fél évszázadon át $s$ azóta is -a hozzá való hüség szimbóluma.

A jelképek világából a földre leszállva azonban nem minden alap nélkül tehetjük fel a kérdést: vajon megfértek-e ök egymás mellett? Milyen volt a viszonyuk a 48-at megelözö reformkor idöszakában, $s$ milyen a forradalom és a szabadságharc napjaiban-heteibenhónapjaiban, ama rövid másfél esztendő alatt? Vajon nem Költő és Politikus megannyi változatban megismétlödő szembenállása-e az övék, amelyben a költő az elveket, az eszményeket képviseli, a politikus pedig a mindennapi lehetőségek és lehetetlenségek között a praktikus elörehaladást?

De ne tévedjünk a publicisztika vizeire! Lássuk, mi kettőjük viszonyának hiteles, történelembe ágyazott tartalma, s abból kibontva az utókorhoz, a mához is szóló üzenete.

Azt lehetne hinni, hogy Kossuth, a jurátus majd ügyvéd, vármegye- majd országgyülés szónoka, az államférfi messze állott az irodalomtól, $\mathrm{s}$ talán ez volt az oka Petőfivel való konfliktusainak. Nem egészen felel meg az igazságnak egy ilyen feltételezés. Persze nem azért, mert - amint szorgalmas filológusok kifürkészték - ifjúkorában öt is megkísértette az irodalom: maga is megpróbálkozott állitólag egy-két korabeli német

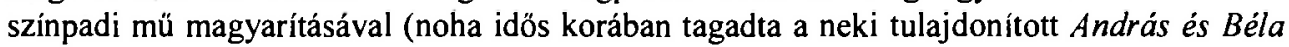
vagy Korona és kard szerzöségét) s nem is azért, mert később, amikor az Országgyülési Tudósitások miatt börtönbe kerül, időtöltésböl valóban hozzákezd Shakespeare Macbethjének forditásához. Ez utóbbi fennmaradt töredékei különben joggal keltették fel az irodalomtörténészek érdeklödését. Csabai Tibor, aki jó negyven évvel ezelött könyvet írt Kossuth Lajos és az irodalom cimmel, igy ír rỏla: ,...még így, töredékes formájában is nagyigényü, a puszta nyelvgyakorláson messze túlmutató, becsvágyról tanúskodó munka ez. Meggyőző erővel példázza azt az egyre formálódó készséget, mely különösen a felfokozott érzelmek nyelvi kifejezésében, az erős szenvedélyek belső hullámzásának. ki-kitörései izgatott mozdulatainak stilisztikai érzékeltetésében már most is igen magas fokot ért el, egyszersmind sejtetve azokat a forrásokat, melyekböl a kossuthi szónoklat és publicisztika magával ragadó ereje táplálkozik."

Kossuthnak tehát - $\mathbf{s}$ itt most már nem az ifjúról, hanem a közéleti pályán magának időkőzben nevet kivivott politikusról van szó - ezek az irodalmi próbảlkozásai az elsöprő hatású szónok és publicista pályáján végigtekintve válnak igazán értelmezhetőekké.

A fiatal Kossuth azonban nem csak kacérkodott az irodalommal - ebben semmi különös nem lett volna abban a korban, amikor a középiskolai oktatásban tantárgy volt a poétika, $\mathrm{s}$ a nebulóknak a verslábak és költői alakzatok ismeretét maguk faragta verseken is bizonyítaniuk kellett - hanem igen korản kapcsolatba került, $\mathbf{s}$ a szabadságharc leveréséig és számüzetéséig kapcsolatban is maradt kora számos jeles magyar írójával. Nem véletlen ez, hiszen az 1830-as - 40-es évek magyar irodalmának legjava azoknak az eszméknek a megfogalmazója, hordozója volt, amelyeket a megyegyüléseken, majd a parlamentben, s a politikai sajtóban Kossuthék igyekeztek a közvéleménnyel elfogadtatni, társadalomátalakitó kezdeményezésekké, tettekké, törvényekkẻ formálni. 
A képzeletbeli névsor élén - nem annyira időrendben, mint inkább a képviselt eszmék történeti rendjében - Kazinczy Ferenc áll, akivel Kossuth a sárospataki kaszinó jegyzőjeként 1831-ben személyesen is találkozott, s aki számára is megtestesítője volt annak a felvilágosodás-kori - majd a nyelvújítási harcban más eszkőzökkel kiteljesedő eszmevilágnak, amelybỏl a nemzeti polgárosodás programja és az egész reformkor kinő. Kötődésük tehát ennek az eszmei folytonosságnak a jelzésértẻkủ aktusa is.

A következỏ lépést Kölcsey jelzi. Az ő kỏzẻleti szereplẻse, a nemesi Magyarország sáncain kívülrekedtek (,,a szegény adózó nép”) felemelése ügyének felvállalása lesz Kossuth példaképe bontakozó politikai pályáján; az ỏáltala megfogalmazott eszmék térnek vissza egyre nagyobb visszhangot kiváltó publicisztikájában: a személyi, a társadalmi, a politikai szabadság eszméje, az érdekegyesítés programja. Amikor Kossuth börtönbe kerül, az egyik könyv, amely odabent vele van, s amelyet naponta forgat, Kölcsey Minden munkájinak egykorú kiadása. A kötödés különben kölcsönös: Kölcsey fogalmazza Szatmár megye feliratát „Kossuth ügyében”, s ezt írja benne: „Kossuth Lajos hazánkfia... magát a nemzet köszönetére érdemessé tevé." Kossuth a börtönben kapja a hírt atyai barátja haláláról, s hallatára így ír Wesselényinek: „Sírnom kellett, mint anyavesztett gyermek sír. - Kölcsey meghalt! miért nem inkább én...?" (Levele 1837. november 30-i keltezéssel.) Egy másik levelében pedig, amelyet édesanyjának küld ki, így jellemzi öt: „Olly sokrateszi bölcsesség, olly catoi character, annyi szerénységgel; olly meleg emberszeretet, olly minden emberi salaktól tiszta szellemiség és személyesített erény olly gyermeki szelidséggel - mikor volt, hol van, s mikor lesz!? (Levele 1838. szeptember 22-röl.)

A harmadik, akinek nagy szerepe van Kossuth egyéniségének, nézeteinek formálódásában: Vörösmarty. Ha Kazinczy az indíték szerepét játszotta, Kölcsey a politikai pálya kiteljesedésének szabott irányt, Vörösmarty volt a Kossth-tal együtt fejlődő-változó eszmetárs. Költői pályája a 30-as évektől valósággal párhuzamban halad a politikusKossuthéval, az irodalomról vallott (egy-két helyen sủrítetten megfogalmazott) elvei, nézetei a nemzeti romantika ideológiai összképébe illeszkedett. Romantikus alkat Kossuth is: nagy eszmékért hevülö, s pátosza erejével sokakat fanatizálni képes. A Szózat, Az országháza, a Liszt Ferenchez strófáit pedig ugyanaz a pátosz hevíti, a nemzet sorsáért érzett ugyanazon felelősség, mint Kossuth beszédeit, akkori nagyhatásủ cikkeit a Pesti Hírlapban. Semmiképpen nem véletlen tehát, hogy amikor kirobban a vita Kossuth és Széchenyi között, Vörösmarty Kossuth oldalán áll sorompóba. És követi majd a szabadságharc idején is a kossuthi politikát, akkor is, amikor érette Petőfi tépi le homlokáról a babért.

Elérkeztünk tehát Petőfihez. S a Kossuth-Petőfi-viszonyt illetően mindjárt egy negatív mozzanat összefüggésében. Pedig Kossuthnak az a néhány írása, amelyekben közvetlenül fogalmazza meg nézeteit az irodalomról, az író szerepéröl abban a felmérhetetlen változásokkal terhes korban, arról tanúskodik, hogy az irodalom kérdéseiben nem is volt közöttük igazi nézetkülönbség. Íme, miképpen vélekedik Kossuth a költészet hatalmáról: „Nemzeti költészet - írja 1842-ben A magyar irodalom és mủvészet 1842-ben címü cikkhez füzött Szerkesztôi megjegyzéseiben - lövelli állócsillagként a nemes érzelmek fénysugarát a népre alkonytalanul; az üdvözíti nemes gerjedelemmel a boldogokat; az csepegtet balzsamírt a boldogtalanok vérző kebelébe, az emeli a népdicsőséget fól egy mennyei diadalig; ...az bír ama büverő tehetségével, melly az egyéni élet prózai mezejének minden szögletén a köznemzeti individualitảs hủrjait megrezgeti." Ímé, hogyan látja az irodalom nemzeti jellegének - és természetesen jelentỏségét - a maga korában: „...a civilizáció, mellynek nemzeties jelleme nincs, hasonlít a levágott gyümölcsvirághoz, mely pohárban még egy-két nap elteng, de gyümölccsé soha nem lesz”. Ės alább: „...kívánatos, $s$ kivált a magyar nemzet és nemzetiség viszonyai közt... kẻtszerte kívánatos, hogy a magyar költö is annyira szívben, lélekben magyar legyen, miszerint önkénytelenül is azon kútföből merítse lelkesedését, melly kútfởnek kiapadhatatlan forrásává kell mủveinek válnia, hogy 
hassanak, és ez a nemzeti érzelem..." És azt is tegyük hozzá, hogy ezt az elvárást az irodalommal szemben egyáltalán nem érzi ellentétesnek az általa szintén felismert és fontosnak tartott egyetemesség-igénnyel: ,...a magyar európaias legyen - írja ugyanitt - s amit európaiasnak nevezünk, a honban mindíg magyar maradjon".

Vajon nem ez a irodalmi program fogalmazódik meg szinte e sorokkal egyidőben Petőfi verseiben, olykor tételesen is? Mi több, épp ezekben az években születnek olyan Petőfi-versek is, amelyek közvetlenül a Kossuth-meghirdette célokhoz kapcsolódnak: a Védegyleti dal a magyar gyártmányú termékek népszerüsítésére indított védegyleti mozgalomnak akár az indulója is lehetne, a Battyhányi és Károlyi grófnék és $A$ külföld magyarjaihoz az idegenség előtti hajbókolás szatírája, illetve a honi értékek felkarolásának apoteózisa.

Mindennek ellenére úgy tünik, az elvek és eszmények szintjén túl, Kossuth költőeszménye mégsem az, amely Petőfiben megtestesül. Lehet, hogy a közvetlenebbül „politizáló" vers lett volna a kedve szerint való, vagy a romantika fennkölt népiessége talajáról érezte ő is „póriasnak" Petỏfinek azt a népiességét, amelyben „a hazafiú érzelmekhez szóló szent egyszerüség" (Kossuth szavai) jut kifejezésre. Tény az, hogy Petőfi költészetére vonatkozó elsỏ közvetlen megnyilatkozásában az elismerésnek még csak az árnya sincs. 1846-ban az Ellenzéki Körben kezdeményezés történik arra, hogy az Életképek c. lapot az ellenzék a maga orgánumának tekintse és fölsorakozzék mögötte. A lapnak Kossuth is küld írást, amit azonban visszavon, amikor látja, hogy a lap munkatársainak sorában a Petőfi neve is ott szerepel. Tiltakozik az ellen, hogy - amint írja - ,neve egy poeta mellett figuráljon". Mire a levél felbontásánál állítólag jelen levő Petőfi így fakad ki: „Vagyok én is olyan ember, mint ö, s még örülni fog, ha az én nevemmel együtt fogják említeni az ơvét is."

Jelentéktelen, a késöbbi visszaemlékezők által felfujt epizód volna? Vagy a jéghegy csúcsa? Illyés Gyula Petöfi-könyvében részletesen kitér a kettöjük közötti alkati különbségekre, s amit mond, az a későbbiekben sokmindenre magyarázatul szolgálhat: „Az ország vezetésének élére kerülő Kossuth annyira az események büvöltje, hogy néha álmodozónak mondható. $\mathrm{S}$ mégis ỏ tán az egész ország leggyakorlatibb s legszorgalmasabb embere... Eszményeivel... »fölgyújtotta«, ahogy ünnepiesen mondani szokták, a magyarok lelkét. $\mathrm{S}$ erre a magasztos tủzre aztán rárakta... a pillanatnyi teendők bögrẻit és lábosait... A költő - aki tökéletesen ismerte a színészi fogásokat - ezeknek a gesztusoknak csak az elejét látta, s azt hitte: kártyákba lát bele. Nem volt igaza... Nem ismerve a másik belsỏ érdemességét, egy lépést sem tett a kőzeledésre... Amikor a kőltő föltünt, Kossuthnak ...már nem maradt érkezése megismerni a handabandázó népdalnokban a költỏt; csak a hírnevét érzékelte s nem verseit... [Kossuth] a híres viddini levében azt írja: a kapára-kaszára kelt parasztok a szabadság nagy költőjének, Vörösmartynak a csatadalait énekelve indultak az ellenségre. Ezt késöbb, nyugodtabb esztendeiben is megismétli. Tudjuk, hogy Vörösmarty nem írt csatadalt... Ilyet a Nemzeti dal szerzöje írt, nem is egyet. Hogy Kossuth ezt akkor sem helyesbíti, amikor már módja lett volna megismerni a segesvári hỏsi halottban a kőltỏt is, amellett szól, hogy sem annak, sem Vörösmartynak nem volt jó olvasója, késỏbb sem."

Ami pedig - az Életképek-afférre visszatérve - azt a pillanatot illeti, a történtek nyilván magyarázhatók azzal is, hogy a kor társadalmi közvélekedésében a ranglistán nem álltak valami magasan a „kicsapott komédiások” (Gyulai Pál később ezzel magyarázza Kossuth elutasító gesztusát), de az olyan vágáns életvitelü költök sem, mint amilyennek akkoriban Petőfit hirdették.

A lényeg azonban - úgy hisszük - mélyebben van: Kossuthban a liberális nemesi ellenzék törekvései, eszményei öltőttek testet, míg Petőfiben már akkor egyre világosabban körvonalazódott egy, az egész világ szabadságára tekintỏ forradalmiság, a rendi korlátokon 
túl az egész nemzetben gondolkodó demokratizmus. És ezzel olyan mércét állított kora elé, amelyhez csak nagyon kevesen tudtak igazán felnőni.

A különbözöség szembetünöen az 1848. márciusi napokban mutatkozik meg. Kossuth számára a forradalom akkor nem több, mint egy politikai alternatíva, amelynek fenyegetését felhasználva eredményeket lehet kicsikarni. Emlékezetes az a pozsonyi diéta feliratával március 15-e után a császári fỏvárosban tartózkodva tett kijelentése, miszerint „ha Bécsben ügyünk hajótörést szenved, lemegyek $s$ magam állok a fiatalok élére”. Ugyanakkor ismeretes az is, amit néhány nappal késöbb, 1848. március 19-i pozsonyi nyilatkozatában mondott: „Pestet elismeri ugyan az ország szivének, de urának nem.”

Különben ez az az idö - a forradalmi márciust követő hónap - amikor Pesten egymás után rendezik a tisztelgö meneteket, fáklyás felvonulásokat hol Klauzál, Wesselényi, Eötvös, hol Batthyányi, Széchenyi, Kossuth tiszteletére, s amikor Petöfi így fakad ki naplójában:

„Mennyi ünnep egy hónap alatt! Vigyázzatok, hogy ezek után a fényes éjek után sötét napok ne következzenek... Borzasztó vásári nép vagyunk! nekünk mindig ünnep kell, és ha egyszer nem lesz emberünk, akit ünnepeljünk, majd a holdvilágnak viszünk fáklyás zenét s csinálunk kivilágítást. Talán azért vagyunk olyan rongyosak, mert mindig ragyogni akarunk."

Igazából ekkor, a forradalom kirobbanása után jön felszínre az, ami öket elválasztja. Íme néhány idézet azokból a mondatokból, amelyekben - az őket csokorba szedő Hatvany Lajos szavai szerint - Kossuth és Petöfi „mintha egymásnak feleselnének”:

Kossuth: ...mi mind e percig a hüség alapján állunk az uralkodóház irányában, mely Ausztriának trónján ül... ebböl oly kapocs következik, melynél fogva némi közös intézkedések mindaddig kikerülhetetlenek, mig a pragmatica sanctió kapcsa fennáll.

Petöfi: Láttam remegést, láttam sápadt arcokat, nem szeretném továbbra is így látni nemzetemnek fiait, - azért most lekötve kardomat, elnyugtatom, de össze nem töröm.

Kossuth: Én egyszerü polgár néhány percig azon helyzetben voltam, hogy e kéz döntőleg határozott az ausztriai trón sorsa fölött, de most is ha azt mondom e leiratra: ,nem kell", - polgárvér folyna a szâvam után, ... de nem képzelhetni undokabb bủnt, mint jảtszani a polgárok vérével s egy nemzet nyugalmával.

Petőfi: ...Meglehet, hogy vér folyt volna, de ti vérontás nélkül akartok átalakulni? isten segítsen, hanem semmi sem lesz belőle. A földnek, hogy termékeny és virító legyen, nemcsak esőre, hanem koronként vérre is van szüksége, és ha idején nem itatjuk meg, később, midőn nagyon megszomjazik, majd kétannyit követel.

Kossuth: Vannak mindenféle egyének, kik rajtam tủlmennek, $s$ én, ki a szabadság elveiért egy életen át küzdöttem, szenvedtem, mérsékeltebb vagyok náloknál.

Petőfi: Ma olvastatott föl a megyei választmányi gyủlésben a minisztériumról szóló királyi leirat. Az ifjúság és így az egész forradalom nagyon elégedetlen vele.

Kossuth: »A nemzetet saját sorsa urának látom; ha egy vagy más kedvenc eszménk nincs is még biztositva, van lehetöség azokat kivívni.«

Petöfi: [...] de a békés polgárok nagyon meg vannak elégedve, $s$ csaknem nyilvảnosan hazaárulóknak nyilatkoztatták azokat, akik ezentúl nyugtalankodni fognak.

Kossuth: Att remélem, hogy a nemzetben van elég erő valóságra érlelni azt, amit e papiroson bír; tartsa meg az erönek azon nemes mérsékletét, melyben fekszik a szabadság diadala. És meg vagyok győződve, hogy a nemzet nagy és boldog leszen.

Petöfi: Jól van, mi nem akarunk hazaárulók lenni, lelépünk és hazamegyünk, de ha e királyi leirat mellett nem lesztek képesek a kellő sikert kivívni, akkor ti lesztek a hazaárulók, ti, kik abban teljesen megnyugodtatok, ti, kik a haza egyedüli reményeinek, az ifjúságnak lelkesedését erkölcsi kényszerítéssel elfojtottátok! 
Kossuth: [A fejedelem] jöjjön le mielöbb hủ magyarjai közẻ s győződjék meg, hogy hủségünk nem puszta szó.

Petőfi: Készülj, hazám, - Készülj, boldog haza! [...] - A bécsi német - Egytöl-egyig mind megveszett $-[\ldots]$ Kegyelmes jó császárjokat elkergetik, - Családostul - [...] De ez lesz a magyarra nézve a - Szerencs napja - [...] - Letérdelünk elöttök, - [...] - És egy kiáltás lesz a nemzet: $-[\ldots]-$, Vitam et sangvinem - pro rege nostro!” Mint hajdanában - Bőgtek dicső apáink. (Készülj, hazám!)

Kossuth: A magyar férfiasan szilárd s öszinte tud lenni, nemcsak szabadsága kivivásában, hanem fejedelme iránti hüségében is.

Petőfi: Most hát oszoljunk szét, ifjú barátaim, kik a két héti nyilvános életben oly bátran és oly csüggedetlenül müködtetek, amint csak ohajtottam, isten veletek, a forradalomnak vége van... de nem, a forradalomnak nincs vége, ez csak az első felvonás volt... a viszonlásásig!

Csodálkoztunk-e azon, hogy egy pesti népgyülésen Petőfi így fakad ki: „Kutyámat se bíznám egy ilyen minisztériumra!"

Az események egymásra torlódásában Kossuth csillaga egyre fonnebb ível: Miniszter az első felelős magyar kormányban, az országgyủlésben a polgári átalakulást jelentő reformok vezérszónoka, majd amikor a bécsi udvar a forradalom fegyveres letörésére szánja el magát, s Jellasics seregei megindulnak a „rebellisek” megregulázására, gyủjtó hatásủ beszédeivel a nemzet önvédelmi harcának kulcsszereplöjẻvé, sőt szimbỏlumává válik. Petőfi politikai pályája ugyanakkor a szabadszállási választási kudarcba fullad, s a márciusi ifjak más személyiségeivel együtt kiszorul a politikai életböl.

A költő azonban jelen van. Söt ekkori verseivel vảlik igazán A Forradalom költöjévé, ébren tartva a lelkekben - $s$ a közvéleményben is - azt a maximumot, amely 48 lényege azóta is.

Az események forgatagában útjaik is összefutnak olykor. Kossuth híres 1848. jủnius 11-i beszédére az Ismét magyar lett a magyar c. verssel felel a költő:

Ismét magyar lett a magyar,

Mert ekkorig nem volt a',

Hogy is lett volna? szolga volt,

S nem magyar, aki szolga!

Ismét magyar lett a magyar,

Bilincsét összetörte,

Mint összel a száraz levél,

Csörögve hull a földre!

Ismét magyar lett a magyar,

Kardot ragad kezébe,

Kardján a napsugár ragyog

$S$ a bátorság szemébe"!

Ismét magyar lett a magyar,

Lángol, piroslik arca,

Kitüzött zászló mindenik,

Amely jelt ád a harcra! 
Ismét magyar lett a magyar,

Egy sziv miljók keblében,

És dobbanása rémület

Az ellenség fülében!

Ismét magyar lett a magyar,

A sikra állt vitézül,

És a világ, a nagyvilág

Csodákat látni készül!

Ismét magyar lett a magyar,

$S$ világvégéig az lesz,

Vagy iszonyúan és dicsön

Mind, mind egy szálig elvesz!

A szeptember 24-i kossuthi kiáltványban foglaltakra az Egyenlőségi Társulat Petőfifogalmazta Proklamációja felel, s egymás mellé állítva, szinte egymásból ihletődöttnek érezhetjük azt, amit a költő egyfelöl, s másfelől a fövárosból 1848 végén menekülni kényszerülő magyar kormány első embere papirra vet:

Petőfi írja az Alföld Hírlapjában 1849. január 9-i keltezéssel: „Megrázott bennünket az ellenség, megrostált; a szemét és a konkoly kihullt, a java meg bennmaradt. Most minden félbarátunk és titkos ellenségünk átmegy a gyözedelmesekhez, s hogy eddig is nem mi vagyunk a győzök, onnan van, mert ezek közöttünk voltak."

Kossuth pedig 1849. január 26-án kelt körlevelében: „,...veszteség által szent ügyünk álbarátait ösmerni tanultuk... A gyáva éppúgy, mint a gaz elmaradozott, hasonlóan a szeméthez, mely a kimosott, leülepedett búzából kiválva, léhaságánál vagy rosszaságánál fogva a víz felületén lebeg."

Az ország súlyos helyzetében, amelyet Petöfi Erdödön jártában közvetlenül is észlelt, épp Karácsony szentestéjén levelet ír Kossuthnak, maga is fegyverrel kívánva felcserélni a tollat:

„Tisztelt Polgártárs! - kezdődik a levél - Nem kérek bocsánatot alkalmatlankodásomért, mert nem a magam, hanem a haza érdekében írom e levelet. Mindenki látja, s Ön legjobban, hogy egynek vagyunk legnagyobb híjában, a vezéreknek. Ha sejtésem nem csal - $s$ az én sejtéseim nem szoktak csalni - bennem van annyi erỏ, hogy ha pályám nyílik, egyike leszek azon vezéreknek, kiknek Magyarország szabadsảgát fogja köszönni. Azért kérem Önt, nevezzen vagy neveztessen ki engem örnagynak, hogy minél előbb saját számadásomra és felelősségemre játszhassam a hazamentés nagy tragédiảjában. Nevezzen ki azon táborhoz, melynek legnagyobb és legnehezebb tennivalói lesznek, mert az én erényem és bátorságom ott éri tetőpontját, hol mások kétségbe esnek."

A forradalmi kormány Debrecenbe menekülésének zürzavarában a levél kẻsve jut el Kossuth-hoz, aki azonban úgy látszik nem reagál az Életképek körüli afférnál sokszorosabban felfokozott költö-hadvezéri öntudat ilyen nyílt kifejezésére, hanem teljesíti a kérés lényegét: elküldi Petöfit Erdélybe, Bem táborába. Ott csinảlja végig a költő-őrnagy a „legnagyobb és legnehezebb tennivalók”-ban bővelkedő tẻli, majd a dicsőséges tavaszi hadjárat csatáit a hamarosan atyjaként tisztelt és szeretett Bem oldalán, aki azonban vigyáz arra, hogy ,a hazamentés nagy tragédiájában" őt megóvja, megvẻdelmezze - ameddig teheti.

Ekkorra már Kossuth is eljutott oda, hogy felismerte: a forradalom vívmányait csak az egész nemzetet mozgósítani képes szabadságharc védheti meg. Igaz, amikor 1849 tavaszán újra összehozza őket a sors - Petőfinek a tábornokokkal való konfliktusa idején - a katonai régulát nem türö Petőfivel szemben amazoknak ad igazat. Akik a kor írói közül 
körülveszik, akiknek közéleti munkáját is igénybe veszi (Vörösmarty, Bajza, Jósika Miklós, Erdélyi János, Sárosi Gyula, Teleki Sándor) ahhoz a nemesi-liberális táborhoz tartoznak, amelyik ővele együtt tette meg az utat a közjogi harctól és parlamentáris reformoktól a forradalomig. Petöfi plebejus-demokratizmusa, forradalmi elszántsága, messze jövendöbe tekintő, annak eszményeit fel nem adó türelmetlensége több, másabb emezek hüségénél, nemzeti elkötelezettségénél. Mégis sor kerül arra, hogy 1849 nyarán, amikor a nemzetnek már az orosz cári intervencióval is szembe kell néznie, amikor - a költő szavai szerint - „itt a próba, az utolsó nagy próba", öt is magához hívja arra a beszélgetésre, amelyen felkéri a megjelent költőket - köztük Aranyt és Petöfit is -. hogy (amint Arany késöbb az esetet felidéző jegyzetében írja) ,fanatisálják” a népet a fỏváros, Pest megvédésére.

Innen azonban már alig néhány hétnyire van a vég: Petőfi számára a fehẻregyházi csatatér, ahol örökre eltünik a földi szemek elöl, Kossuth számára pedig a számüzetẻs.

A Habsburg-elnyomatás, majd a kiegyezés évtizedei azok, amikor Kossuth és Petőfi neve egymás mellé kerül a nemzeti tudatban. Hogy miként, azt legpontosabban Vajda János egy Petőfit idéző kései, 1884-es cikkében fogalmazta meg: „Ứgy vagyunk vele, mint a turini önkéntes száműzöttel és az általa képviselt eszmékkel: nem követjük, de szíveinkben népszerübb, kegyeltebb, mint azok közül bárki, aki ma »aktuális«."

(Kézdivásárhely, 2002. október 15.) 
